\title{
Czechoslovak environment
}

SIR - Western observers shocked by the extent of environmental damage in Czechoslovakia $^{1,2}$ may not be aware of the close relationship between democracy and environmental protection. In Western democracies, the environment is protected in the interplay of government, nongovernmental organizations and unbiased science. In the former Soviet Union and Eastern Europe, science has been deformed as a result of previous government control and marxist ideology. Environmental science was almost neglected in Czechoslovakia; the Academy of Sciences, for example, had no environmental programme.

Even so, several institutes and universities studied the environmental degradation on a limited scale. Their results were usually not made publicly available; their dissemination was partly prohibited by law ${ }^{4}$. These studies are summarized in two reviews ${ }^{3,4}$ issued after the political change in 1989: the 'federal' report ${ }^{3}$ written in 1989 by a team of scientists and environmentalists, and the 'Czech' report ${ }^{4}$ written in 1990 by a team of the Czech Ministry of Environment.

The number of references in corresponding chapters of both texts is limited as well as their availability (see table). The references are not properly marked in the text, which indicates poor practice in using scientific information. The small number of primary sources cited in the federal report is obviously because of their limited availability in 1989. We have experienced this problem in reviewing the use and fate of polychlorinated biphenyls in Czechoslovakia ${ }^{5}$. The number of references given in the Czech report, which was completed after the political change, is, however, even lower (see table), and parts of the text are identical with the federal report, for example, 80 per cent of the text of the chapter "Living Nature".

By using the Science Citation Index (SCI), one can guess the publication activity of the authors of the federal report and the authors of citations used in both reports (see table). A group of 50 environmental scientists was created randomly for a comparison using the contents of recent issues of seven international journals (Chemosphere, Environ. Intern., Environ. Pollut., Intern. Environ. Study, J. appl. Ecol., J. exp. Marine Biol., Ecol. and J. Freshwater Ecol.). According to the SCI, 1990, 67 per cent of the international group is mentioned in papers of other scientists compared with 25 per cent of the authors of the federal report.

Both reports contain primary data on human health, air, water and soil pollu- tion that are unavailable elsewhere. As the measuring techniques are not mentioned, it is difficult to compare these data with results of others. A better situation seems to obtain in the biological sciences ("Living Nature") where authors could publish their studies. It can be concluded that normal scientific communication and processing of information has not been developed in Czechoslovak environmental science. This may

inhibit the public understanding of the environmental situation in the country. LUBOS NONDEK

Water Research Institute,

Podbabska 30 ,

16000 Prague 6 ,

Czechoslovakia

1. French, H. F. State of the World 1991 (ed. Brown, L. R.) Ch. 6 (W. W. Norton, New York, 1991)

2. Hamilton, J. M. Bull. Atom. Scientists 47, 12 (1991)

3. Vavrousek, J. et al. State and Trends of the Environment in Czechosiovakia, 3rd Edition (Cesky svaz ochrancu prirody, Praha, 1990, in Czech).

4. Moldan, B. et al. Environment of the Czech Republic Academia Praha 1990, (in Czech).

NUMBERS OF RELEVANT AND AVAILABLE REFERENCES AND THE CITATION OF THEIR AUTHORS IN SCIENTIFIC LITERATURE

\begin{tabular}{lcccccc}
\hline Chapter* & \multicolumn{3}{c}{ Czech report (1990) } & \multicolumn{3}{c}{ Federal report (1989) } \\
& Ref $\neq$ & Avail.§ & Cit.(\%) & Ref $\neq$ & Avail.§ & Cit.(\%) \\
Air & 6 & 1 & 0 & 7 & 1 & 0 \\
Water & 5 & 0 & 0 & 9 & 3 & 0 \\
Soil & 9 & 2 & 0 & 12 & 2 & 0 \\
Living nature & 15 & 9 & 70 & 15 & 9 & 70 \\
Xenobiotics $\dagger$ & 5 & 2 & 60 & 5 & 2 & 60 \\
Forestry & 11 & 4 & 15 & 33 & 9 & 30
\end{tabular}

* See the titles in English edition of the Czech report issued by Czech Ministry of environmental protection without (sic!) Tables and Figures; the compared parts represent 26 per cent (the Czech report) and 77 per cent (Federal report) of the text. $\dagger$ "Aitochtonous Substances" in English edition. $\ddagger$ Only sources relevant to Czechoslovak environment accounted $\S$ All books and periodic journals are supposed to be publicly available.

\section{Brownian emotion}

SIR - Recently, in an abstract ${ }^{1}$, Daniel H. Deutsch has argued that Robert Brown ${ }^{2,3}$ could not have seen the random motion of small particles, later called brownian motion. Deutsch's main arguments are that Brown's system was too noisy, that he did not use coverslips (not yet invented), that his particles were too large (for example pollen grains), too light or too heavy, and that a proper achromatic microscope had not yet been invented. Deutsch says that to see real brownian motion in water at magnifications of $350 \times$ requires particles of approximately 1 micrometre and a rigid system free from vibration and evaporation.

To learn what Brown really saw in 1827, there are two requirements; a careful reading of Brown's publications and use of his (mainly single lens) microscopes. Both courses have been followed by Brian Ford ${ }^{4}$, who gives a vivid description of Brown's findings as well as the discovery and restoration of one of Brown's microscopes, at present at the Linnean Society in London. It is not clear that Deutsch used these methods. If he had read Brown's papers more thoroughly, he would have noted that Brown did not describe the movements of pollen grains, which indeed are too large for Brownian motion, but described movements of particles inside pollen grains (see also the title of his paper). Brown estimate the size of these particles as $1 / 15,000$ to $1 / 20,000$ of an inch $(1.7-1.3 \mu \mathrm{m})$. Later, he added that, using other single lens microscopes as well as the best achromatic compound microscopes available, he could see movements of even smaller particles (down to $1 / 30,000$ of an inch $=0.85$ $\mu \mathrm{m})$.

A careful reading of Brown's observations refutes most of Deutsch's arguments. The particles were not too large, but of the required size of around $1 \mu \mathrm{m}$. Brown makes sure that the motions were not due to currents in the fluid nor to its gradual evaporation, a problem he was well aware of.

To diminish currents due to evaporation, Brown even immersed small droplets of water, containing his microscopic particles, in almond oil. The 'brownian' motion remained visible. He also mentions that, in some grasses, the membrane of the pollen was so transparent that motion of the particles could be seen inside the intact pollen grains, where currents or evaporation can be excluded as a cause of the movements observed. Our conclusion, therefore, must be that Brown did see real Brownian motion.

Gerhard C. CADÉE Netherlands Institute for Sea Research, PO Box 59, 1790 AB Texel,

The Netherlands

1. Deutsch, D.H. Bull. Amer. Phys. Soc. 36, 1374 (1991)

2. Brown R A brief account of microscopical observations made in the months of June, July and August, 1827, on the particles contained in the pollen of plants and the general existence of active molecules (printed privately. London, 1828).

3. Brown, R. Additional remarks on active molecules (printed privately, London, 1829). (Both papers reprinted in The Miscellaneous Botanical Works of Robert Brown (ed. Bennett. JJ) 1. 463-486 (Roy Soc. London, 1866)

4. Ford, B.J. Single lens, the story of the simple micro scope (Harper \& Row, New York, 1985). 